\title{
Effect of Irrigation and Nitrogen Fertiziation on Sugar Beet Yield, Quality and Some Water Relations in Heavy Clay Soils
}

\author{
Moursi, E.A. and R.Kh. Darwesh ${ }^{1}$
}

\begin{abstract}
Two field experiments during the winter seasons 2012/2013 and 2013/2014 were conducted at the North Nile Delta region Sakha Agricultural Research Station $\operatorname{Farm}\left(31^{-} \mathbf{0 7}^{\circ} \mathrm{N}\right.$ Latitude, $30^{-} 5^{\circ} \mathrm{E}$ longitude) to investigate the water behavior of sugar beet (Beta vulgaris L.) crop under different rates and doses of nitrogen fertilization on yield, some yield attributes, quality and some water relations. A split-split plot design with four replicates was used in the present study, where the main plots were randomly assigned by irrigation treatments which were irrigation at 55,70 and $85 \%$ depletion of available soil moisture $\left(I_{1}, I_{2}\right.$ and $I_{3}$, respectively). While, sub-main plots were also randomly assigned by nitrogen rates which were $N_{1}, N_{2}$ and $N_{3}$ (application of 30,60 and $90 \mathrm{~kg} \mathrm{~N} /$ fed., respectively). Also, sub-sub main plots were randomly assigned by nitrogen doses which were as one, two equal and three equal doses through the growing season $D_{1}, D_{2}$ and $D_{3}$, respectively. The results indicated that the highest values of water applied, consumptive use and water storage were recorded under $I_{1}$ in the two growing seasons and the values were $(2751.0,2790,4)$, $(2235.5,2250.2)$ and $2300.13,2325.96 \mathrm{~m}^{3} /$ fed. On the contrary, the lowest values of the above-mentioned studied parameters were recorded under $I_{3}$ and the values were 2259.6, 2293.2 and 1800.0, 1832.1 and 1990.18 and 2045.41 $\mathrm{m}^{3} /$ fed. For water applied, consumptive use and water storage in the first and second seasons, respectively. Concerning with water productively (WP) and productivity of irrigation water (PIW), the highest mean values were recorded under $I_{1}$ and the mean values were $13.94,14.01 \mathrm{~kg} / \mathrm{m}^{3}$ for $W P$ and11.34, $11.30 \mathrm{~kg} / \mathrm{m}^{3}$ for PIW, but the lowest mean values were recorded under $I_{3}$ and the values were $12.65,12.55 \mathrm{~kg} / \mathrm{m}^{3}$ and 10.08 and $10.03 \mathrm{~kg} / \mathrm{m}^{3}$ for WP and PIW in the first and second seasons, respectively.
\end{abstract}

Regarding water application efficiency, the highest mean values were recorded under $I_{3}$ and the values are 88.08, 89.19\% but the lowest mean values were recorded under $I_{1}$ and the values are 83.61 and $83.36 \%$ in the first and second seasons, respectively. Concerning the effect of nitrogen rates and doses on consumptive use, WP and PIW, the highest mean values were recorded under $N_{3}$ and $D_{3}$. Data showed water storage and water application efficiency were slightly affected by both nitrogen rates and doses. Sugar beet root yield, top yield and root diameter were highly significant affected by irrigation treatments, nitrogen rates and doses in the two growing seasons. Where, the mean values for the abovementioned studied parameters were increased with increasing water applied,

${ }^{1}$ Soils, Water and Environment Research Institute, ARC, Giza, Egypt Received August 18, 2014, Accepted September 2014 nitrogen rates and doses. Although root length increased with decreasing amount of irrigation water applied.

Sugar yield, purity, nitrogen concentration in tops and roots increased with increasing irrigation water, nitrogen rates and doses. On the other hand, sucrose percentage increased with decreasing irrigation water and nitrogen rates but increased with nitrogen doses.

Kay words: sugar beet irrigation, water consumptive use, water productivity, nitrogen doses and rates

\section{INTRODUCTION}

Irrigation water is gradually becoming scarce not only in arid and semi-arid regions but also in the regions where rainfall is abundant. Egypt is a country of water scarcity due to general low precipitation, high evaporation and the temporal and spatial distribution of rainfall. Therefore, water saving and conservation is a vital and essential demand to face the water gap problem and support agriculture activities which account of $85 \%$ of the total water consumed in semiarid regions. In irrigation agriculture it is necessary to optimize water management and increase the efficiency of water productivity by a group of technical procedures providing the information needed to irrigate at the optimal frequency and time. (Singh and Chauman, 1996). So, Irrigation is one of the most important inputs in agricultural practices and particularly in all crops cultivation to increase crop productivity.

The development, use and future prospects of irrigation in agriculture are described with particular reference to sugar beet. Approximately $40 \%$ of the world's sugar beet fields are currently irrigated, and the average annual increase of the acreage of irrigated sugar beet has been $9 \%$ over the last twenty years, with significant variations from country to another. The improvements in irrigation systems in recent years have given great increases in yield. In arid zones, the increase in demand is the main cause of the shortage of water. Future alternatives being discussed in some regions include the limitation of supply and an increase in the price of water, Morillo-Velarde,-R (2000).

Crop water management and its yield at different environments are very important concern in irrigation planning and maximizing yield (Sepaskhah et al. 1997) reported that frequent every ever-other furrow irrigation at 10 days irrigation intervals used a smaller amount of irrigation water, but some yield reduction occurred. 
However, frequent every-other furrow irrigation at 6 days intervals produced a similar root yield to that every furrow irrigation at 10 days intervals and saved about $23 \%$ of irrigation water. Crop yield may be increased if proper irrigation practices are used. Improving drought tolerance of commercial verities of sugar beet may be a promising approach in maximizing water use efficiency (Rytter, 2005).But sugar beet breeding is along-term and expensive. An efficient way of assessing the extent and complexity of the water stress problem in sugar beet production throughout Europe may be to use crop growth muddling approach to evaluate the effects of future climatic. Scenarios(Richer et al., 2001).

The irrigation number, amount and uniformity of water application are used mainly to determine the efficiency of irrigation scheduling. Excessive doses of infrequently applied water will lead to high percolation losses. There is still competition for water by the agricultural, domestic and industrial uses during the dry season, hence, there is need for formers to conserve and make judicious use of available water (Adekalu and Okunade, 2006 and Ancuta et al., 2007). (Kayombo et al., 2002)Indicated that the crop water use efficiency has been shown to depend on irrigation amount and frequency, also, the type of irrigation system and tillage practices can influence the water use efficiency for a given irrigation frequency.(Byan et al., 2002) Inducted that the water consumptive use (WCU) of cowpea amounted to $0.426,0.532$ and $0.639 \mathrm{~m}^{3} \mathrm{~m}^{-2}$ when irrigated by 80,100 and $120 \%$ of water calculated by class a pan method, respectively.

Proper irrigation timing can maximize sugar beet yields while minizing diseases, water costs, fertilizer leaching and soil erosion. Crop yields can suffer from either under or over irrigation. Under irrigation limits water flow into the plant, which reduces movement of water nutrients and photosynthesis within the plant. Over irrigation reduces yield through increased incidence of diseases, loss of nutrients from the soil root zone and reduced oxygen to roots. Over irrigation reduces sugar beet quality by lowering the sugar percentage. Sugar beet plants have a deep root system, enabling them to use soil water from as deep as 6 feet. However, if water is abundant, sugar beets will satisfy the majority of their water requirements from the top two feet of soil. In addition, excess moisture can cause the top root to rot resulting in a shallow, sprongled root system. Young sugar beet plants should not be stressed for moisture. Frequent, light, irrigations encourage rapid foliage production and plant establishment. Later in the season, irrigation can be spaced apart to ensure the top/ foot of soil never gats drier than $50 \%$ available soil moisture (El-Mowelhi et al., 1999 and abo Soliman et al., 2005).
Sugar beet has become one of the major winter field crop in Egypt due to its high income to the farmers and also it considered the second producing sugar crop after sugar cane. Therefore, the sugar beet crop has received a wide attention from different aspects, because it supplies nearly half the world's requirements of sugar (Singhania and sharma, 1990). Sugar beet is an excellent for sugar production in Egypt. Its area trended to increase year after another to meet the increasing population demands. Great efforts are presently made in Egypt to increase demand of consumption. Higher yielded of any crop is the main goal of many current researchers. Irrigation and fertilizer are important and limiting factors for sugar beet production under Egypt conditions. Complete and balanced fertilization is important for high crop production. Many investigators reported that nitrogen is the most limiting nutrient for sugar beet (Al Attar et al., 1995, Khalifa and Header, 1995, Rezk et al., 1995 and Moursi, E. A. 1997)

Because of the agricultural sector is the main for water consumption in comparison with other sectors as abovementioned. So, effective management at the irrigation sector is the principal way towards the rationalization policy of the country. In this aspect effective on farm irrigation management becomes a must. In addition to, the importance of sugar beet as a crop for sugar production to face the increasing bad need for population sugar requirements. Also, the importance of nitrogen nutrient in sugar production. So, the main targets of this present study were to:

- Study water behavior of sugar beet under the condition of the studied area,

- Investigate the effect of irrigation treatments on yield, yield components and sugar quality,

- Study the effect of irrigation treatments on some water relations,

- Study the effect of nitrogen rates and doses on yield, yield components and sugar yield and quality,

- Investigate the effect of irrigation treatments and nitrogen fertilization on nitrogen concentration by sugar beet tops and roots, and

- Study all the interaction effects among studied treatments on sugar beet yield, yield components, sugar quality and some water relations.

\section{MATERIALS AND METHODS}

Two field investigations were conducted at Sakha Agricultural Research Station Farm, during the two growing seasons 2012/2013 and 2013/2014 to study the effect of water behavior of sugar beet under different rates and doses of nitrogen and study the effect of these treatments on sugar beet yield, yield attributes, quality 
and some water relationships in the North Middle Nile Delta region. The site lies at Kafr EL Sheikh Governorate. Which located at $\left(31^{\circ} 07^{-} \mathrm{N}\right.$ Latitude, $30^{\circ}$ $57^{-}$longitude) with an elevation of about 6 metres above mean sea level.

Soil samples were analyzed in the Central Laboratory for Soil, Water and Plant Studies in Soils, Water and Environment Research Institute (SWERI), Agricultural Research Center (ARC). Soil samples were taken from the experimental site at four depths; 0-15, $15-30,30-45$ and $45-60 \mathrm{~cm}$, to determine physical and chemical characteristics of the soil before cultivation. Bulk density, Field capacity and permanent wilting point were determined according to (Klute 1986), Available water was calculated as a difference between field capacity and permanent wilting point, soil $\mathrm{pH}$ was measured in soil water suspension (Jackson, 1973), total soluble salts were measured in saturated soil paste extract (Jackson, 1973). Soluble cations and anions were determined in soil paste extract (Jackson, 1973).

Data presented in Table (2) shows the meteorological parameters during the studied period, recorded from Sakha Agrometeorological Station. The meteorological parameters, include; air temperature $\left(\mathrm{T} . \mathrm{C}^{\circ}\right)$,relative humidity $(\mathrm{RH} ., \%)$, wind speed $\left(\mathrm{U}_{2}, \mathrm{~km} /\right.$ day at $2 \mathrm{~m}$ height) and evaporation pan (Ep, $\mathrm{mm} / \mathrm{day})$.

\section{Experimental layout}

Sugar beet (Farida cultivar) as a winter crop was planted on $20^{\text {th }}$ and $25^{\text {th }}$ October and harvested on $1^{\text {st }}$ and $4^{\text {th }}$ April in the first and second growing seasons, respectively. All cultured practices for the crop were the same as recommended for the studied area and crop expect the studied parameter (irrigation treatments, nitrogen rates and doses). The plot area for irrigation treatment is $100 \mathrm{~m}^{3}$ (20m in length and $5 \mathrm{~m}$ in width) $1 / 42$ fed.

\section{The experimental design}

The experimental design of current study was splitsplit plot design with four replicates. The main plot were randomly assigned to three irrigation treatments, sub main plot were also randomly assigned to three nitrogen rates and sub sub main plots were randomly assigned to three nitrogen doses which were three.

\section{A. Main treatments (irrigation)}

$\mathrm{I}_{1}$ : Irrigation at $55 \%$ depletion of available soil moisture,

$\mathrm{I}_{2}$ : Irrigation at $70 \%$ depletion of available soil moisture, and

$\mathrm{I}_{3}$ : Irrigation at $85 \%$ depletion of available soil moisture.

B. Sub main treatments (nitrogen rates)

$\mathrm{N}_{1}$ : application of $30 \mathrm{~kg} \mathrm{~N} / \mathrm{fed}$,

$\mathrm{N}_{2}$ : application of $60 \mathrm{~kg} \mathrm{~N} / \mathrm{fed}$, and

$\mathrm{N}_{3}$ : application of $90 \mathrm{~kg} \mathrm{~N} /$ fed.

\section{Sub-sub main treatments (nitrogen doses)}

$\mathrm{D}_{1}$ : Application nitrogen requirements as one dose through the season,

$\mathrm{D}_{2}$ : Application nitrogen requirements as two doses through the season, and

$\mathrm{D}_{3}$ : Application nitrogen requirements as three doses through the season.

Table 1. Mean value of some soil physical and chemical properties of the studied site before sugar beet cultivation in the two growing seasons

\begin{tabular}{|c|c|c|c|c|c|c|c|c|c|c|}
\hline \multicolumn{11}{|c|}{ Soil physical properties } \\
\hline \multirow{2}{*}{$\begin{array}{c}\text { Soil depth } \\
\mathrm{Cm} \\
\end{array}$} & \multicolumn{3}{|c|}{ Particle size distribution } & \multirow{2}{*}{$\begin{array}{c}\text { Texture } \\
\text { class }\end{array}$} & \multirow{2}{*}{\multicolumn{2}{|c|}{$\begin{array}{c}\text { Bulk Density, } \\
\mathrm{kg} / \mathrm{m}^{3}\end{array}$}} & \multirow{2}{*}{ F.C. $\%{ }^{*}$} & \multirow{2}{*}{ P.W.P \% ${ }^{* *}$} & \multirow{2}{*}{\multicolumn{2}{|c|}{$\begin{array}{c}\text { Available } \\
\text { water \% }\end{array}$}} \\
\hline & Sand $\%$ & Silt \% & Clay\% & & & & & & & \\
\hline $0-15$ & 26.00 & 28.00 & 46.00 & Clayey & \multicolumn{2}{|c|}{1.19} & 47.00 & 25.30 & & 21.70 \\
\hline $15-30$ & 29.00 & 23.00 & 48.00 & Clayey & \multicolumn{2}{|c|}{1.16} & 39.00 & 21.80 & & 17.20 \\
\hline $30-45$ & 26.50 & 26.00 & 47.50 & Clayey & \multicolumn{2}{|c|}{1.30} & 38.00 & 21.90 & & 16.10 \\
\hline $45-60$ & 27.50 & 25.50 & 47.00 & Clayey & \multicolumn{2}{|c|}{1.20} & 38.50 & 20.80 & & 17.70 \\
\hline Mean & 27.25 & 25.63 & 47.13 & Clayey & \multicolumn{2}{|c|}{1.21} & 40.63 & 22.45 & & 18.18 \\
\hline \multicolumn{11}{|c|}{ Soil chemical properties } \\
\hline \multirow{2}{*}{$\begin{array}{c}\text { Soil depth } \\
\text { cm }\end{array}$} & \multirow[b]{2}{*}{ pH } & \multirow{2}{*}{$\begin{array}{c}\text { EC } \\
\text { dS/m }\end{array}$} & \multicolumn{4}{|c|}{ Soluble cations, meq/l } & \multicolumn{4}{|c|}{ Soluble anions meq/l } \\
\hline & & & $\mathrm{Ca}^{++}$ & $\mathrm{Mg}^{++}$ & $\mathrm{Na}^{+}$ & $\mathrm{K}^{+}$ & $\mathrm{CO}_{3}{ }^{=}$ & $\mathrm{HCO}_{3}^{-}$ & $\mathrm{Cl}^{-}$ & $\mathrm{SO}_{4}=$ \\
\hline $0-15$ & 8.15 & 1.50 & 0.30 & 0.10 & 0.76 & 0.02 & - & 0.55 & 0.21 & 0.42 \\
\hline $15-30$ & 8.00 & 1.57 & 0.31 & 0.10 & 0.79 & 0.02 & - & 0.57 & 0.22 & 0.43 \\
\hline $3045-$ & 8.00 & 1.65 & 0.34 & 0.10 & 0.89 & 0.02 & - & 0.65 & 0.23 & 0.47 \\
\hline $45-60$ & 7.90 & 2.78 & 0.84 & 0.27 & 1.25 & 0.03 & - & 0.45 & 0.23 & 1.71 \\
\hline Mean & 8.01 & 1.88 & 0.45 & 0.14 & 0.92 & 0.02 & - & 0.56 & 0.22 & 0.76 \\
\hline
\end{tabular}

*F.C.: Field capacity, **P.W.P: Permanent wilting point. 
Table 2. Some meteorological data in the two growing seasons 2012/2013 and 2013/2014

\begin{tabular}{|c|c|c|c|c|c|c|c|c|c|}
\hline \multirow[b]{2}{*}{ Months } & \multicolumn{3}{|c|}{$\mathbf{T}\left(\mathbf{c}^{\circ}\right)$} & \multicolumn{3}{|c|}{ RH(\%) } & \multirow{2}{*}{$\begin{array}{c}\mathrm{U}_{2} \\
\mathrm{~m} / \mathrm{Sec}\end{array}$} & \multirow{2}{*}{$\begin{array}{c}\text { Pan } \\
\text { Evap. } \\
\text { (mm/day) }\end{array}$} & \multirow{2}{*}{$\begin{array}{l}\text { Rain } \\
\text { mm }\end{array}$} \\
\hline & Max. & Min. & Mean & Max. & Min. & Mean & & & \\
\hline \multicolumn{10}{|c|}{$2012 / 2013$} \\
\hline Oct. 2012 & 29.92 & 20.64 & 25.28 & 85.24 & 55.30 & 70.27 & 0.86 & 4.30 & 6.57 \\
\hline Nob. 2012 & 25.32 & 15.47 & 20.40 & 89.53 & 61.80 & 75.67 & 0.66 & 1.87 & 28.20 \\
\hline Dec. 2012 & 21.35 & 10.52 & 15.94 & 84.77 & 60.83 & 72.80 & 0.73 & 2.55 & 13.02 \\
\hline Jun. 2013 & 19.22 & 7.62 & 13.42 & 91.06 & 65.35 & 78.21 & 0.52 & 1.99 & 78.74 \\
\hline Feb. 2013 & 20.68 & 8.88 & 14.78 & 89.89 & 64.04 & 76.97 & 0.73 & 2.89 & $\begin{array}{ll}----- \\
\end{array}$ \\
\hline Mar. 2013 & 24.56 & 12.45 & 18.51 & 79.48 & 50.84 & 65.16 & 1.03 & 4.46 & 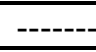 \\
\hline April 2013 & 26.04 & 15.87 & 20.96 & 74.20 & 43.90 & 59.05 & 1.11 & 5.30 & 8.40 \\
\hline \multicolumn{10}{|c|}{$2013 / 2014$} \\
\hline Oct. 2013 & 27.79 & 19.42 & 23.61 & 76.23 & 57.36 & 66.80 & 1.26 & 2.87 & -ב---- \\
\hline Nob. 2013 & 25.39 & 15.14 & 20.27 & 87.00 & 64.43 & 75.72 & 0.80 & 2.28 & ------ \\
\hline Dec. 2013 & 19.64 & 8.51 & 14.06 & 92.07 & 67.61 & 79.84 & 0.61 & 4.15 & 81.9 \\
\hline Jun. 2014 & 20.34 & 7.55 & 13.95 & 93.69 & 70.55 & 80.55 & 0.54 & 1.60 & 20.7 \\
\hline Feb. 2014 & 20.64 & 8.19 & 14.42 & 91.90 & 67.15 & 79.53 & 0.79 & 2.52 & 16.5 \\
\hline Mar. 2014 & 22.94 & 11.71 & 17.33 & 86.10 & 56.80 & 71.45 & 0.96 & 3.14 & 26.2 \\
\hline April 2014 & 27.50 & 15.53 & 21.52 & 81.80 & 49.80 & 65.8 & 1.07 & 4.91 & 20.2 \\
\hline
\end{tabular}

*source: meteorological station at Sakha $31^{\circ} 07^{-} \mathrm{N}$ Latitude, $30^{\circ} 57^{-}$longitude with an elevation of 6 metres above mean sea level.

\section{Data collection}

\section{Water relationships}

\section{Amount of irrigation water applied $\left(\mathrm{m}^{3} / \mathrm{fed}\right)$}

Amount of irrigation water applied for each irrigation was measured and then seasonal water applied was recorded by using cut throat flume $(30 * 90 \mathrm{~cm})$ through the whole growing season and calculated as $\mathrm{m}^{3} /$ fed according to Early,(1975).

\section{Water consumptive use $\left(\mathrm{m}^{3} /\right.$ fed.)}

To compute the actual consumed water of the growing plants, soil moisture percentage was determined (on Weight basis) before and after each irrigation as well as at harvesting. Soil samples for moisture determination were taken from successive soil layers each $20 \mathrm{~cm}$ depth for a total depth of $60 \mathrm{~cm}$, by auger. The soil samples were weighted after sampling immediately and dried in an electric oven to a constant weight at $105^{\circ} \mathrm{c}$. Percentage of soil moisture content at the four soil depths $(0-20,20-40,40-60)$ was calculated on an oven-dry basis. The amount of water consumed in each irrigation was obtained from the difference between soil moisture content after and before the following irrigation. Water consumptive use by growing plants was calculated based on soil moisture depletion (SMD) according to Hansen et al, (1979).

$$
C U=S M D=\sum_{i=1}^{i=N} \frac{\Theta 2-\theta_{1}}{100} * D b i * D i * 4200
$$

Where

$\mathrm{Cu}=$ Water consumptive use in the effective root zone $(60 \mathrm{~cm})$,

$\Theta 2=$ Gravimetric soil moisture percentage after irrigation,

$\Theta 1=$ Gravimetric soil moisture percentage before irrigation,

$\mathrm{Db}_{\mathrm{i}}=$ soil bulk density $(\mathrm{Kg} / \mathrm{m} 3)$ for depth,

$\mathrm{D}_{\mathrm{i}}=$ Soil layer depth $(20 \mathrm{~cm})$, and

$1=$ number of soil layers (1-3).

3. Stored water in the effective root zone $\left(\mathrm{m}^{3} /\right.$ fed.)

Seasonal stored water (SW)in the effective root zone was calculated by using the following equation

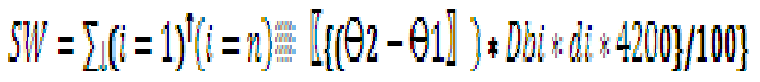

Where:

SW: Seasonal stored water in the effective root zone

$\Theta 2=$ soil moisture \%after irrigation in the $\mathrm{i}$ th layer, (i.e. directly, before and after the same irrigation

$\Theta 1=$ soil moisture \%before irrigation in the $\mathrm{i}$ th layer,

$\mathrm{Di}=$ Soil layer depth $(20 \mathrm{~cm})$, and

$1=$ number of soil layers (1-3). 


\section{Water efficiencies}

\section{4-1- water application efficiency (WAE)}

Water application efficiency (WAE)was calculated according to Israelsen and Hansen (1962).

$$
W . A . E=\frac{\text { total water stored in ef fective root zone }}{\text { total water opplied }}+100
$$

\section{4-2-water productivity (WP, $\mathrm{Kg} / \mathrm{m}^{3}$ )}

Water productivity is generally defined as crop yield per cubic metre of water consumption. Water productivity can be also defined as crop production per unit amount of water used (Molden,1997). Concept of water productivity in agricultural production system is focused on producing more food with the same water resources or, producing the same amount of food with less water resources. Water productivity was calculated according to Ali et al, (2007).

$$
W P={ }^{Y} / E T
$$

Where:

$\mathrm{WP}=$ water productivity $\left(\mathrm{kg} / \mathrm{m}^{3}\right)$

$\mathrm{Y}=$ root yield $(\mathrm{kg} / \mathrm{fed}$.

$\mathrm{ET}=$ total water consumption of the growing season $\mathrm{m}^{3} /$ fed.

\section{4-3- productivity of irrigation water $\left(\mathrm{PIW}, \mathrm{kg} / \mathrm{m}^{3}\right)$}

Productivity of irrigation water (PIW)as calculated according to Ali et al (2007).

$$
\begin{aligned}
& P I W={ }^{Y} I_{I} \\
& \text { Where } \\
& \text { PIW = productivity of irrigation water }\left(\mathrm{kg} / \mathrm{m}^{3}\right), \\
& \mathrm{Y} \quad=\text { root yield } \mathrm{kg} / \mathrm{fed}, \text { and } \\
& \mathrm{I} \quad=\text { irrigation water applied } \mathrm{m}^{3} / \text { fed. }
\end{aligned}
$$

\section{Yield, yield components and quality}

\section{5-1- Yield (ton/fed.)}

The yield of plot was weighted and computed as:

a- Root yield (ton/fed.),

b- Top yield (ton/fed.), and

c- Sugar yield (ton/fed.)obtained by multiplying root yield by sucrose percentage

\section{5-2- Growth parameters}

Root length and diameter.

At harvesting time (200 day from planting) random sample of ten plants were chosen from each plot to determine some plant parameters of sugar beet growth i.e root diameter and root length $(\mathrm{cm})$. Also, some characters of sugar beet roots quality have been measured and calculated such as sucrose \%, the purity (qz\%), were measured at Delta Sugar Company Limited Laboratories at Kafer El.sheikh Governorate .

Plant samples (Tops and roots) were collected from each plot at the end of growing season. Each sample was rinsed distilled water thoroughly and dried in an oven at $65 \mathrm{C}^{\circ}$ for 24 hours. One gram of each sample was wet digested according to the method described by Chapman and Pratt (1961), where the samples were digested in $\mathrm{H}_{2} \mathrm{SO}_{4} \quad \mathrm{H}_{2} \mathrm{O}_{2}$ mixture to determine the concentration of nitrogen in both tops and roots, where total nitrogen concentration was determined by micro Kejeldahl method.

\section{Statistical analysis}

All data were statistically analyzed according to the technique of analysis of variance (ANOVA) as published by Gomez and Gomez (1984). Means of the treatment were compared by the least significant difference (LSD) At 5\% level of significance which developed by (Waller and Duncan 1969).

\section{RESULTS AND DISCUSSIONS}

\section{Amount of seasonal water applied}

Tabulated data in table (3) clearly illustrated that the seasonal amounts of irrigation water applied were affected by irrigation treatments $\left(\mathrm{I}_{1}, \mathrm{I}_{2}\right.$, and $\left.\mathrm{I}_{3}\right)$ in the two growing seasons. Applied water consists of two components; irrigation water (I.W.) and rainfall (RF). The highest values for amount of seasonal water applied were recorded under irrigation treatment $I_{1}$ and the values were $2751.0 \mathrm{~m}^{3} /$ fed. $(65.50 \mathrm{~cm})$ and $2790.4 \mathrm{~m}^{3} / \mathrm{fed}$. (66.44 cm.) in the first and second growing season, respectively. On the other hand, the lowest values were recorded under irrigation treatment $\mathrm{I}_{3}$ and the values were $2259.6 \mathrm{~m}^{3} / \mathrm{fed}(53.8 \mathrm{~cm}$.) and $2293.2 \mathrm{~m}^{3} / \mathrm{fed}$. $(54.60 \mathrm{~cm}$.) in the first and second growing season, respectively. In general, the values of seasonal amount of water applied could be descended in order $\mathrm{I}_{1}>\mathrm{I}_{2}>\mathrm{I}_{3}$. Increasing the values of seasonal water applied under irrigation treatment $\mathrm{I}_{1}$ comparing with the other treatments $I_{2}$ and $I_{3}$ might be attributed to increasing number of irrigations under the conditions of this treatment because of decreasing irrigation interval between waterings. While, the water applied for sugar beet crop under traditional irrigation in the studied area is $3245.76 \mathrm{~m}^{3}$ (according to Mona S. M. Eid 2012). These results are in agreement with those obtained by Sepaskhah and Kamgar. Haghighi (1997), Richer et al, (2001),Panda et al,(2004), Ancuta et al,(2007), Shabana (2010), Gharib and El-henawy (2011), Mona.S.M. Eid (2012), and Beshara,A.T (2012) who reported that the highest values for seasonal water applied for wheat crop 

Table 3. Effect of irrigation treatments on seasonal amount of water applied in the two growing seasons

\begin{tabular}{|c|c|c|c|c|c|c|}
\hline \multirow{2}{*}{$\begin{array}{c}\text { Irrigation } \\
\text { treatments (I) }\end{array}$} & \multicolumn{2}{|c|}{$\begin{array}{c}1^{\text {st }} \text { growing season } \\
\text { Seasonal water applied }\end{array}$} & \multicolumn{2}{|c|}{$\begin{array}{c}2^{\text {nd }} \text { growing season } \\
\text { Seasonal water applied }\end{array}$} & \multicolumn{2}{|c|}{$\begin{array}{l}\text { Overall mean values for } \\
\text { the two growing seasons }\end{array}$} \\
\hline & $M^{3} /$ fed & $\mathbf{c m}$ & $M^{3} /$ fed & $\mathbf{c m}$ & $M^{3} /$ fed & $\mathbf{c m}$ \\
\hline $\mathrm{I}_{1}$ & 2751.0 & 65.50 & 2790.4 & 66.44 & 2770.7 & 65.97 \\
\hline $\mathrm{I}_{2}$ & 2509.5 & 59.75 & 2574.6 & 61.30 & 2542.1 & 60.5 \\
\hline $\mathrm{I}_{3}$ & 2259.6 & 53.8 & 2293.2 & 54.60 & 2276.4 & 54.2 \\
\hline
\end{tabular}

were recorded under irrigation at $50 \%$ depletion of available soil moisture comparing with irrigation at 70 and $90 \%$ depletion of available soil moisture. Data in the same table also illustrated that the seasonal amount of water applied were not affected by nitrogen rater and doses in the two seasons.

\section{Water Consumptive use for sugar beet crop}

Presented data in Table (4) and figure (1) clearly showed that the mean values of sugar beet consumptive use were affected by irrigation treatments, nitrogen rates, and doses in the two growing seasons. The highest mean value for sugar beet consumptive use was recorded under irrigation treatment $I_{1}$ and the highest overall mean value during the two growing seasons is $2242.9 \mathrm{~m}^{3} /$ fed. $(53.4 \mathrm{~cm})$. On the other hand, the lowest overall mean value during the two growing seasons was recorded under irrigation treatment $\mathrm{I}_{3}$ and the value is $1816.1 \mathrm{~m}^{3} /$ fed. $(43.3 \mathrm{~cm})$. The overall mean values for sugar beet consumptive use can be descended in order $I_{1}>I_{2}>I_{3}$ in the two growing seasons. Increasing the mean values of sugar beet consumptive use under irrigation treatment I1 (which received a large number of waterings) comparing with other irrigation treatments $I_{2}$ and $I_{3}$ (which exposed to water stress through the growing season by receiving a low number of waterings might be attributed to increasing number of irrigations under the conditions of this treatment because of decreasing irrigation intervals. So, increasing amount of water applied and hence increasing the values of consumptive use. These results coincided with those obtained by Shabana (2010), Gharib and El-henawy (2011), Mona.S.M. Eid (2012), and Beshara, (2012) and Aiad et al, (2014). They concluded that the highest mean values for maize consumptive use were recorded under irrigation at $45 \%$ depletion of available soil moisture comparing with irrigation at 60 and $75 \%$ depletion of available soil moisture.

Concerning with the effect of nitrogen rates and doses, the highest overall mean values for sugar beet consumptive use were recorded under the highest rate of nitrogen application $\mathrm{N}_{3}$ and splitting nitrogen into three equal doses $\mathrm{D}_{3}$ in comparison with other nitrogen rates and doses. Increasing the mean values of sugar beet consumptive use under $\mathrm{N}_{3}$ and $\mathrm{D}_{3}$ in the two growing season might be attributed to increasing availability of soil nutrients and hence, increasing uptake rate of these nutrients. Therefore, forming strong plants with thick vegetative cover. Consequently increasing amount of water consumed by plants to compensate the large amount of water losses by evaporation as a result of increasing exposed surface area for plants to the sunlight under the conditions of nitrogen application rate $\left(\mathrm{N}_{3}\right)$ and splitting nitrogen into three equal doses $\left(D_{3}\right)$. These results agreed with those obtained by Shabana (2010), Gharib and El-henawy (2011), Mona.S.M. Eid (2012), and Beshara (2012) and Aiad et al,(2014).

-Water storage in the effective root zone $\left(\mathrm{m}^{3} /\right.$ fed.) and water application efficiency $(\%)$.

Data in table (5) clearly illustrated that the mean values of water storage in the effective root zone were affected by irrigation treatments $I_{1}, I_{2}$ and $I_{3}$ in the two growing seasons. The highest mean values were recorded under irrigation treatment $I_{1}$ and the mean values are 2300 . and $2325.96 \mathrm{~m}^{3} / \mathrm{fed}$. On the other hand, the lowest mean values were recorded under irrigation treatment $\mathrm{I}_{3}$ and the mean values are 1990.18 and $2045.41 \mathrm{~m}^{3} / \mathrm{fed}$, in the first and second growing season, respectively. In general, the mean values of water storage in the effective root zone can be descended in order $\mathrm{I}_{1}>\mathrm{I}_{2}>\mathrm{I}_{3}$ in the two growing season. Regarding the effect of nitrogen rates and doses, the mean values of water storage in the effective root zone were slightly affected by both nitrogen rates and doses.

Increasing the mean values of water storage under irrigation treatment $\mathrm{I}_{1}$ comparing with other irrigation treatments $\mathrm{I}_{2}$ and $\mathrm{I}_{3}$ in the two growing seasons might be due to increasing amount of water applied by decreasing irrigation intervals. So, plants find an easy way to take their water requirements and a large amount of water still stay in the effective root zone. Therefore, increasing amount of water storage. These findings are in a great agreement with those obtained by Bashara (2012) and Aiad et al, (2014). 
Table 4. Effect of irrigation treatments, nitrogen rates and doses on the values of consumptive use in the two growing seasons

\begin{tabular}{|c|c|c|c|c|c|c|c|c|}
\hline \multirow{3}{*}{$\begin{array}{l}\text { Irrigation } \\
\text { treatments } \\
\text { (I) }\end{array}$} & \multirow{3}{*}{$\begin{array}{l}\text { Nitrogen } \\
\text { rates } \\
(\mathbf{N})\end{array}$} & \multirow{3}{*}{$\begin{array}{l}\text { Nitrogen } \\
\text { doses } \\
\text { (D) }\end{array}$} & \multirow{2}{*}{\multicolumn{2}{|c|}{$\begin{array}{l}\mathbf{1}^{\text {st }} \text { growing season } \\
\text { Consumptive Use }\end{array}$}} & \multirow{2}{*}{\multicolumn{2}{|c|}{$\begin{array}{c}2^{\text {nd }} \text { growing season } \\
\text { Consumptive Use }\end{array}$}} & \multirow{2}{*}{\multicolumn{2}{|c|}{$\begin{array}{c}\text { Overall mean } \\
\text { values for the two } \\
\text { growing season }\end{array}$}} \\
\hline & & & & & & & & \\
\hline & & & $\mathrm{m}^{3} /$ fed & $\mathrm{cm} /$ fed & $\mathrm{m}^{3} /$ fed & $\mathrm{cm} / \mathrm{fed}$ & $\mathrm{m}^{3} / \mathrm{fed}$ & $\mathrm{cm} / \mathrm{fed}$ \\
\hline \multirow{11}{*}{$\mathrm{I}_{1}$} & \multirow{3}{*}{$\mathrm{N}_{1}$} & D1 & 2170.7 & 51.7 & 2190.8 & 52.2 & 2180.8 & 52.0 \\
\hline & & D2 & 2190.3 & 52.2 & 2198.7 & 52.4 & 2194.5 & 52.3 \\
\hline & & D3 & 2198.7 & 52.4 & 2210.3 & 52.6 & 2204.5 & 52.5 \\
\hline & \multicolumn{2}{|l|}{ Mean $\mathrm{N}_{1}$} & 2186.6 & 52.1 & 2199.9 & 52.4 & 2193.3 & 52.3 \\
\hline & \multirow{3}{*}{$\mathrm{N}_{2}$} & D1 & 2200.7 & 52.4 & 2210.3 & 52.6 & 2205.5 & 52.5 \\
\hline & & $\mathrm{D} 2$ & 2210.8 & 52.6 & 2220.7 & 52.9 & 2215.8 & 52.8 \\
\hline & & D3 & 2240.7 & 53.4 & 2250.8 & 53.6 & 2245.8 & 53.5 \\
\hline & Mean $\mathrm{N}_{2}$ & & 2217.4 & 52.8 & 2227.3 & 53.0 & 2222.4 & 52.9 \\
\hline & \multirow{3}{*}{$\mathrm{N}_{3}$} & D1 & 2290.7 & 54.5 & 2308.7 & 55.0 & 2299.7 & 54.8 \\
\hline & & D2 & 2295.7 & 54.7 & 2310.8 & 55.0 & 2303.3 & 54.9 \\
\hline & & D3 & 2320.8 & 55.3 & 2350.6 & 56.0 & 2335.7 & 55.7 \\
\hline & Mean $\mathrm{N}_{3}$ & & 2302.4 & 54.8 & 2323.4 & 55.3 & 2312.9 & 55.1 \\
\hline Mean $\mathrm{I}_{1}$ & & & 2235.5 & 53.2 & 2250.2 & 53.6 & 2242.9 & 53.4 \\
\hline \multirow{12}{*}{$\mathrm{I}_{2}$} & \multirow{3}{*}{$\mathrm{N}_{1}$} & D1 & 2070.7 & 49.3 & 2090.8 & 49.8 & 2080.8 & 49.6 \\
\hline & & D2 & 2090.3 & 49.8 & 2110.7 & 50.3 & 2100.5 & 50.1 \\
\hline & & D3 & 2102.8 & 50.1 & 2118.8 & 50.4 & 2110.8 & 50.3 \\
\hline & \multicolumn{2}{|l|}{ Mean $\mathrm{N}_{1}$} & 2087.9 & 49.7 & 2106.8 & 50.2 & 2097.4 & 50.0 \\
\hline & \multirow{3}{*}{$\mathrm{N}_{2}$} & D1 & 2120.3 & 50.5 & 2148.3 & 51.2 & 2134.3 & 50.9 \\
\hline & & D2 & 2130.8 & 50.7 & 2160.8 & 51.4 & 2145.8 & 51.1 \\
\hline & & D3 & 2155.9 & 51.3 & 2165.7 & 51.6 & 2160.8 & 51.5 \\
\hline & \multicolumn{2}{|l|}{ Mean $\mathrm{N}_{2}$} & 2135.7 & 50.9 & 2158.3 & 51.4 & 2147.0 & 51.2 \\
\hline & \multirow{3}{*}{$\mathrm{N}_{3}$} & D1 & 2180.7 & 51.9 & 2190.3 & 52.2 & 2185.5 & 52.1 \\
\hline & & $\mathrm{D} 2$ & 2185.8 & 52.0 & 2200.7 & 52.4 & 2193.3 & 52.2 \\
\hline & & D3 & 2207.3 & 52.6 & 2210.8 & 52.6 & 2209.1 & 52.6 \\
\hline & \multicolumn{2}{|l|}{ Mean $\mathrm{N}_{3}$} & 2191.3 & 52.2 & 2200.6 & 52.4 & 2196.0 & 52.3 \\
\hline \multicolumn{2}{|l|}{ Mean $\mathrm{I}_{2}$} & & 2138.3 & 50.9 & 2155.2 & 51.3 & 2146.8 & 51.1 \\
\hline \multirow{12}{*}{$\mathrm{I}_{3}$} & \multirow{3}{*}{$\mathrm{N}_{1}$} & D1 & 1720.8 & 41.0 & 1790.8 & 42.6 & 1755.8 & 41.8 \\
\hline & & D2 & 1760.2 & 41.9 & 1800.7 & 42.9 & 1780.5 & 42.4 \\
\hline & & D3 & 1790.7 & 42.6 & 1810.5 & 43.1 & 1800.6 & 42.9 \\
\hline & \multicolumn{2}{|l|}{ Mean $\mathrm{N}_{1}$} & 1757.2 & 41.8 & 1800.7 & 42.9 & 1779.0 & 42.4 \\
\hline & \multirow{3}{*}{$\mathrm{N}_{2}$} & D1 & 1760.8 & 41.9 & 1790.8 & 42.6 & 1775.8 & 42.3 \\
\hline & & D2 & 1790.7 & 42.6 & 1810.3 & 43.1 & 1800.5 & 42.9 \\
\hline & & D3 & 1800.8 & 42.9 & 1813.7 & 43.2 & 1807.3 & 43.1 \\
\hline & \multicolumn{2}{|l|}{ Mean $\mathrm{N}_{2}$} & 1783.8 & 42.5 & 1804.9 & 43.0 & 1794.4 & 42.8 \\
\hline & & D1 & 1830.8 & 43.6 & 1880.6 & 44.8 & 1855.7 & 42.2 \\
\hline & $\mathrm{N}_{3}$ & D2 & 1870.8 & 44.5 & 1890.3 & 45.0 & 1880.6 & 44.8 \\
\hline & & D3 & 1875.3 & 44.7 & 1900.8 & 45.3 & 1888.1 & 45.0 \\
\hline & Mean $\mathrm{N}_{3}$ & & 1859.0 & 44.3 & 1890.6 & 45.0 & 1874.8 & 44.7 \\
\hline Mean $\mathrm{I}_{3}$ & & & 1800.0 & 42.9 & 1832.1 & 43.6 & 1816.1 & 43.3 \\
\hline
\end{tabular}



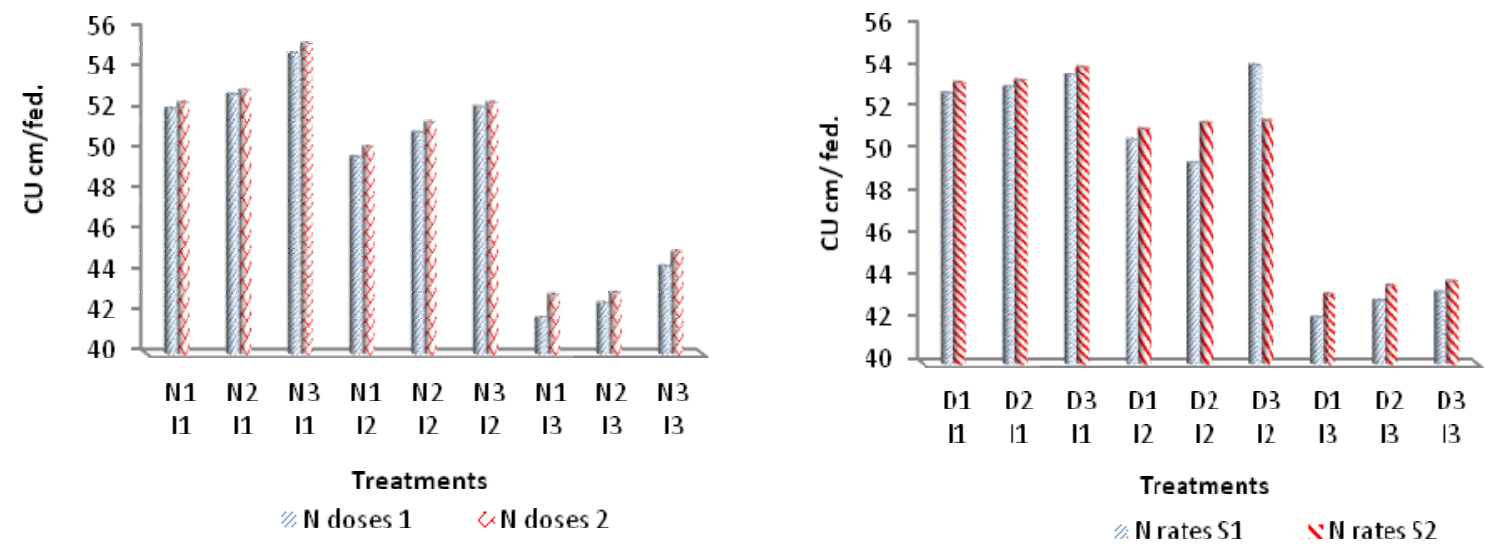

Fig. 1. Consumptive use as affected by $\mathbf{N}$ doses and $\mathbf{N}$ rates

Table 5. Effect of irrigation treatments on stored water in the effective root zone and water application efficiency in the two growing seasons

\begin{tabular}{|c|c|c|c|c|}
\hline \multirow{2}{*}{$\begin{array}{c}\text { Irrigation } \\
\text { treatments (I) }\end{array}$} & \multicolumn{2}{|c|}{$1^{\text {st }}$ growing season } & \multicolumn{2}{|c|}{$2^{\text {nd }}$ growing season } \\
\hline & $\begin{array}{c}\text { Stored water in the } \\
\text { effective root zone } \\
\mathrm{m}^{3} / \mathrm{fed}\end{array}$ & $\begin{array}{c}\text { Water } \\
\text { application } \\
\text { efficiency }(\%)\end{array}$ & $\begin{array}{c}\text { Stored water in the } \\
\text { effective root zone } \\
\mathrm{m}^{3} / \mathrm{fed}\end{array}$ & $\begin{array}{c}\text { Water } \\
\text { application } \\
\text { efficiency (\%) }\end{array}$ \\
\hline $\mathrm{I}_{1}$ & 2300.13 & 83.61 & 2325.96 & 83.36 \\
\hline $\mathrm{I}_{2}$ & 2201.17 & 87.71 & 2218.15 & 86.16 \\
\hline $\mathrm{I}_{3}$ & 1990.18 & 88.08 & 2045.41 & 89.19 \\
\hline
\end{tabular}

Data in the same table showed that the mean values of water application efficiency were clearly affected by irrigation treatments and slightly affected by both nitrogen rates and doses. The highest mean values were recorded under irrigation treatment $\mathrm{I}_{3}$ (which exposed to water stress) in the two growing seasons and the mean values are 88.08 and $89.19 \%$ but the lowest mean values were recorded under irrigation $I_{1}$ and the mean values are 83.61 and $83.63 \%$ in the first and second growing seasons, respectively. Increasing the mean values of water application efficiency under irrigation treatment $\left(I_{3}\right)$ in comparison with $I_{2}$ and $I_{3}$ might be attributed to decreasing amount of water applied under the conditions of this treatment.

Water productivity and productivity of irrigation water $\left(\mathrm{Kg} / \mathrm{m}^{3}\right)$.

Tabulated data in Table (6) and figure (2\&3) clearly declared that the mean values of water productivity (WP) and productivity of irrigation water (PIW) were affected by irrigation treatments, nitrogen rates and doses. Concerning with the effect of irrigation treatments the highest mean values for the two irrigation efficiencies were recorded under irrigation treatment $\left(\mathrm{I}_{1}\right)$ in the two growing seasons and the mean values are $13.97,14.01,11.34$ and $11.30 \mathrm{Kg} / \mathrm{m}^{3}$. On the contrary, the lowest mean values were recorded under irrigation treatment $\mathrm{I}_{3}$ and the mean values are $12.65,12.55$ and 10.08 and $10.03 \mathrm{Kg} / \mathrm{m}^{3}$ for (WP) and (PIW) in the first and second growing seasons, respectively. Generally, the mean vales for WP and PIW can be descended in order $I_{1}>I_{2}>I_{3}$ in the two growing seasons. Increasing the mean values of (WP) and (PIW) under irrigation treatment $\mathrm{I}_{1}$ in comparison with $\mathrm{I}_{2}$ and $\mathrm{I}_{3}$ may be due to increasing root yield under the conditions of this treatment. These results are in a great harmony with those obtained by Gharib and El-henawy (2011).

Regarding, the effect of nitrogen rates and doses, the highest mean values were recorded under nitrogen rate $\left(\mathrm{N}_{3}\right)$, splitting nitrogen into three equal doses $\left(\mathrm{D}_{3}\right)$ under irrigation treatment $\mathrm{I}_{1}$ in the two growing seasons. Generally, the highest mean values for (WP) and (PIW) were recorded under $\mathrm{I}_{1} \mathrm{~N}_{3} \mathrm{D}_{3}$ in the two growing season.

Effect of irrigation treatments, nitrogen rates and doses on sugar beet yield, yield components, quality and nitrogen content in tops and roots.

\section{1- Sugar beet root yield (ton/fed)}

Presented data in Table (7) clearly illustrated that the mean values of sugar beet root yield were highly significant affected by irrigation treatments, nitrogen rates and doses in the two growing seasons. Concerning 
with the effect of irrigation treatments, the highest mean values were recorded under irrigation treatment $I_{1}$ and the mean values are 31.20 and 31.56 ton/fed. On the other hand, the lowest mean values were recorded under irrigation treatment $\mathrm{I}_{3}$ and the values are 22.77 and 23.00 Ton/fed. In the first and second growing season, respectively. Generally, the mean values of sugar beet root yield can be descended in order $\mathrm{I}_{1}>\mathrm{I}_{2}>\mathrm{I}_{3}$. Increasing the mean values of sugar beet root yield under irrigation treatment $I_{1}$ which received a large amount of irrigation water applied because of increasing amount of water. So, increasing solubility of soil nutrients and hence increasing availability of these nutrients, therefore, increasing uptake rate of these nutrients this improves and increases root yield under the conditions of this treatment comparing with other stressed treatments $\mathrm{I}_{2}$ and $\mathrm{I}_{3}$. These results are in a great harmony with those

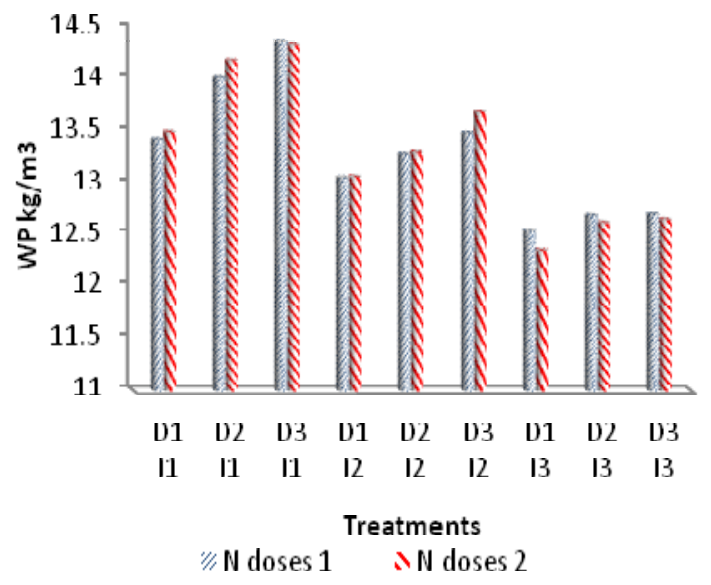

obtained by Gharib and El-henawy (2011), and Aiad et al, (2014).

Regarding, the effect of nitrogen application rates, the mean values of sugar beet yield were highly significant affected by nitrogen application rate where the highest mean values were recorded under nitrogen rate $\mathrm{N}_{3}$ and the values are 28.77 and $29.12 \mathrm{Ton} / \mathrm{fed}$. On the contrary, the lowest mean values for sugar beet root yield were recorded under nitrogen application rate $\mathrm{N}_{1}$ and the values are 26.22and 26.51Ton/fed. in the first and second growing season, respectively. Generally the mean values for sugar beet root yield can be descended in order $\mathrm{N} 3>\mathrm{N} 2>\mathrm{N} 1$ in the two growing seasons. These results are supported by studies of many authors, Marinkovic et al (2010), Selim et al (2010), Gharib and EL-Henawy (2011) and Aiad et al (2014).

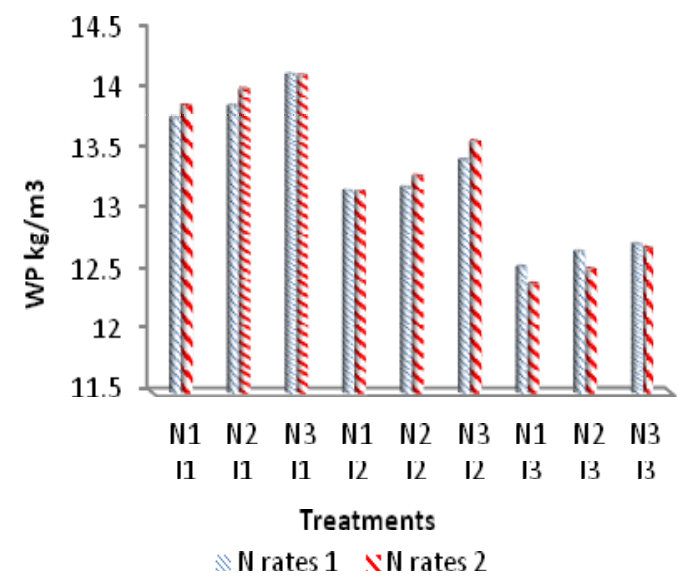

Fig. 2. Water productivity as affected by $\mathrm{N}$ doses and $\mathrm{N}$ rates
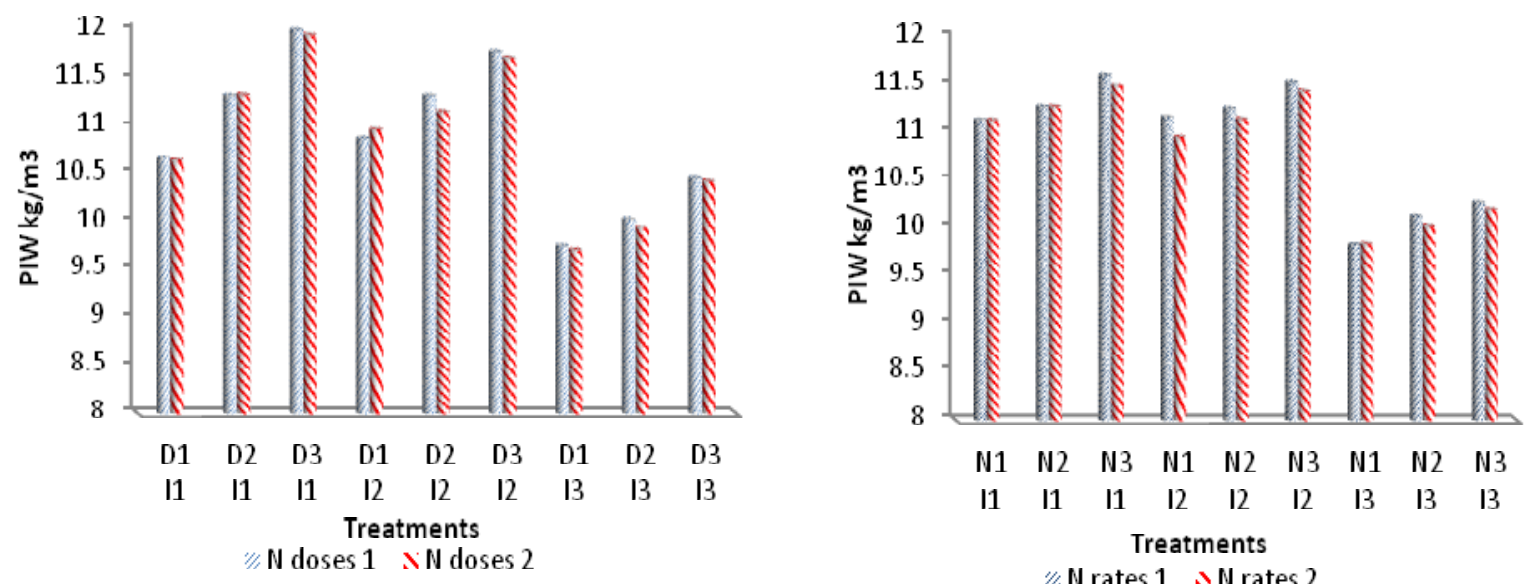

Fig. 3. Productivity of irrigation water as affected by $\mathrm{N}$ doses and $\mathrm{N}$ rates 
Table 6. Effect of irrigation treatments, nitrogen rates and doses on water productivity (WP, $\mathrm{Kg} / \mathrm{m}^{3}$ ) and productivity of irrigation water $\left(\mathrm{PIW}, \mathrm{Kg} / \mathrm{m}^{3}\right.$ ) for sugar beet in the two growing seasons

\begin{tabular}{|c|c|c|c|c|c|c|}
\hline \multirow{2}{*}{$\begin{array}{c}\text { Irrigation } \\
\text { treatments (I) }\end{array}$} & \multirow{2}{*}{$\begin{array}{l}\text { Nitrogen } \\
\text { rates }(\mathrm{N})\end{array}$} & \multirow{2}{*}{$\begin{array}{l}\text { Nitrogen } \\
\text { doses (D) }\end{array}$} & \multicolumn{2}{|c|}{$1^{\text {st }}$ growing season } & \multicolumn{2}{|c|}{$2^{\text {nd }}$ growing season } \\
\hline & & & $\begin{array}{c}\mathbf{W P}, \mathbf{K g} \\
/ \mathbf{m}^{3}\end{array}$ & PIW, Kg /m3 & $\begin{array}{c}\text { WP, Kg } \\
/ / \mathbf{m 3}\end{array}$ & $\begin{array}{c}\text { PIW, Kg } \\
\quad / \mathbf{m 3}\end{array}$ \\
\hline \multirow{12}{*}{$\mathrm{I}_{1}$} & \multirow{3}{*}{$\mathrm{N}_{1}$} & $\mathrm{D}_{1}$ & 13.22 & 10.43 & 13.28 & 10.43 \\
\hline & & $\mathrm{D}_{2}$ & 13.38 & 10.65 & 13.51 & 10.64 \\
\hline & & $\mathrm{D}_{3}$ & 13.69 & 10.94 & 13.71 & 10.86 \\
\hline & Mean $\mathrm{N}_{1}$ & & 13.43 & 10.67 & 13.50 & 10.64 \\
\hline & \multirow{3}{*}{$\mathrm{N}_{2}$} & $\mathrm{D}_{1}$ & 13.90 & 11.12 & 14.07 & 11.15 \\
\hline & & $\mathrm{D}_{2}$ & 13.93 & 11.20 & 14.23 & 11.32 \\
\hline & & $\mathrm{D}_{3}$ & 14.24 & 11.60 & 14.26 & 11.50 \\
\hline & Mean $\mathrm{N}_{2}$ & & 14.02 & 11.31 & 14.19 & 11.32 \\
\hline & \multirow{3}{*}{$\mathrm{N}_{3}$} & $\mathrm{D}_{1}$ & 14.23 & 11.85 & 14.29 & 11.83 \\
\hline & & $\mathrm{D}_{2}$ & 14.33 & 11.96 & 14.32 & 11.86 \\
\hline & & $\mathrm{D}_{3}$ & 14.56 & 12.29 & 14.42 & 12.15 \\
\hline & Mean $\mathrm{N}_{3}$ & & 14.37 & 12.03 & 14.34 & 11.95 \\
\hline Mean $\mathrm{I}_{1}$ & & & 13.94 & 11.34 & 14.01 & 11.30 \\
\hline \multirow{12}{*}{$\mathrm{I}_{2}$} & \multirow{3}{*}{$\mathrm{N}_{1}$} & $\mathrm{D}_{1}$ & 12.94 & 10.68 & 12.96 & 10.53 \\
\hline & & $\mathrm{D}_{2}$ & 13.01 & 10.84 & 12.98 & 10.64 \\
\hline & & $\mathrm{D}_{3}$ & 13.22 & 11.08 & 13.26 & 10.91 \\
\hline & Mean $\mathrm{N}_{1}$ & & 13.06 & 10.87 & 13.07 & 10.69 \\
\hline & \multirow{3}{*}{$\mathrm{N}_{2}$} & $\mathrm{D}_{1}$ & 13.21 & 11.16 & 13.08 & 10.91 \\
\hline & & $D_{2}$ & 13.23 & 11.24 & 13.37 & 11.23 \\
\hline & & $\mathrm{D}_{3}$ & 13.41 & 11.52 & 13.44 & 11.30 \\
\hline & Mean $\mathrm{N}_{2}$ & & 13.28 & 11.31 & 13.30 & 11.15 \\
\hline & \multirow{3}{*}{$\mathrm{N}_{3}$} & $\mathrm{D}_{1}$ & 13.39 & 11.64 & 13.47 & 11.46 \\
\hline & & $D_{2}$ & 13.40 & 11.68 & 13.54 & 11.57 \\
\hline & & $\mathrm{D}_{3}$ & 13.68 & 12.03 & 14.07 & 12.08 \\
\hline & Mean $\mathrm{N}_{3}$ & & 13.49 & 11.78 & 13.69 & 11.70 \\
\hline Mean $\mathrm{I}_{2}$ & & & 13.28 & 11.32 & 13.35 & 11.18 \\
\hline \multirow{12}{*}{$\mathrm{I}_{3}$} & \multirow{3}{*}{$\mathrm{N}_{1}$} & $\mathrm{D}_{1}$ & 12.49 & 9.51 & 12.22 & 9.55 \\
\hline & & $\mathrm{D}_{2}$ & 12.50 & 9.74 & 12.27 & 9.64 \\
\hline & & $\mathrm{D}_{3}$ & 12.62 & 10.00 & 12.59 & 9.94 \\
\hline & Mean $\mathrm{N}_{1}$ & & 12.54 & 9.75 & 12.36 & 9.71 \\
\hline & \multirow{3}{*}{$\mathrm{N}_{2}$} & $\mathrm{D}_{1}$ & 12.49 & 9.74 & 12.40 & 9.68 \\
\hline & & $\mathrm{D}_{2}$ & 12.79 & 10.13 & 12.71 & 10.03 \\
\hline & & $\mathrm{D}_{3}$ & 12.83 & 10.22 & 12.79 & 10.12 \\
\hline & Mean $\mathrm{N}_{2}$ & & 12.70 & 10.03 & 12.63 & 9.94 \\
\hline & \multirow{3}{*}{$\mathrm{N}_{3}$} & $\mathrm{D}_{1}$ & 12.67 & 10.27 & 12.60 & 10.33 \\
\hline & & $\mathrm{D}_{2}$ & 12.72 & 10.53 & 12.64 & 10.42 \\
\hline & & $\mathrm{D}_{3}$ & 12.74 & 10.58 & 12.73 & 10.55 \\
\hline & Mean $\mathrm{N}_{3}$ & & 12.71 & 10.46 & 12.66 & 10.43 \\
\hline Mean $\mathrm{I}_{3}$ & & & 12.65 & 10.08 & 12.55 & 10.03 \\
\hline
\end{tabular}

Concerning with the effect of splitting nitrogen, data in the same table clearly showed that, the mean values of sugar beet root yield were highly significant affected by splitting nitrogen into doses in comparison with application it as one dose. The highest mean values were recorded under $\mathrm{D}_{3}$ and the mean values are 28.02 and $28.32 \mathrm{Ton} / \mathrm{fed}$. in the first and second growing seasons, respectively. Generally, the mean values of sugar beet root yield can be descended in order
$\mathrm{D}_{3}>\mathrm{D}_{2}>\mathrm{D}_{1}$ in the two seasons. Increasing the mean values of root yield under $\mathrm{D}_{3}$ might be attributed to under splitting process the fertilizer losses is low. So, increasing uptake rate and hence, give agood root yield. These results are in the same line with those reported by El-Agrodi et al .(2011,) Beshara(2012) and Aiad et al.(2014).

Data in the same Table also showed that, the interaction between $\left(I^{*} \mathrm{~N}\right)$ is highly significant effect in 
the two seasons. While I*D showed Significant effect through the two seasons, but the interactions among $\left(N^{*} D\right)$ and $\left(I^{*} N^{*} D\right)$ showed no significant effect in the second season.

\section{2- Top Yield (Ton/fed), root length (cm.) and root diameter $(\mathbf{c m})$.}

Data in Table (7) illustrated that, irrigation treatments have a high significant effect on the abovementioned studied parameters where the highest mean values for top yield and root diameters, were recorded under irrigation treatment $\left(\mathrm{I}_{1}\right)$ but the lowest mean values were recorded under $\mathrm{I}_{3}$ in the two growing seasons. Concerning with the root length the highest mean values were recorded under irrigation treatment $\mathrm{I}_{3}$ but the lowest were recorded under $\mathrm{I}_{1}$ in the two seasons. These results are in a great harmony with those obtained by Shabana (2010) and Gharib and ELHenawy (2011).Data in the same Table also showed that both nitrogen rates and doses have a high significant effect on the above mentioned three studied parameters where the highest mean values were recorded under $\mathrm{N}_{3}$ and $\mathrm{D}_{3}$. On the contrary, the lowest mean vales were recorded under $\mathrm{N}_{1}$ and $\mathrm{D}_{1}$ in the two growing seasons. Concerning with the interaction effects on top yield root diameter and root length, all

Table 7. Effect of irrigation treatments, nitrogen rates and doses on sugar beet yield and its components in the two growing seasons

\begin{tabular}{|c|c|c|c|c|c|c|c|c|}
\hline \multirow{2}{*}{$\begin{array}{c}\text { Treatment } \\
\text { s }\end{array}$} & \multicolumn{4}{|c|}{$1^{\text {st }}$ growing seasons } & \multicolumn{4}{|c|}{$2^{\text {nd }}$ growing seasons } \\
\hline & $\begin{array}{c}\text { Root } \\
\text { yield } \\
\text { (Ton/fed) }\end{array}$ & $\begin{array}{c}\text { Top } \\
\text { yield } \\
\text { (Ton/fed } \\
\text { ) }\end{array}$ & $\begin{array}{c}\text { Root } \\
\text { length } \\
\text { (cm.) }\end{array}$ & $\begin{array}{c}\text { Root } \\
\text { diameter } \\
\text { (cm.) }\end{array}$ & $\begin{array}{c}\text { Root } \\
\text { yield } \\
\text { (Ton/fed) }\end{array}$ & $\begin{array}{c}\text { Top } \\
\text { yield } \\
\text { (Ton/fed } \\
\text { ) }\end{array}$ & $\begin{array}{c}\text { Root } \\
\text { length } \\
\text { (cm.) }\end{array}$ & $\begin{array}{c}\text { Root } \\
\text { diameter } \\
\text { (cm.) }\end{array}$ \\
\hline \multicolumn{9}{|c|}{ Irrigation treatments (I) } \\
\hline $\mathrm{I}_{1}$ & 31.20 & 13.46 & 28.64 & 10.87 & 31.56 & 14.05 & 28.24 & 11.22 \\
\hline $\mathrm{I}_{2}$ & 28.39 & 11.75 & 29.89 & 10.03 & 28.79 & 12.39 & 29.73 & 10.26 \\
\hline $\mathrm{I}_{3}$ & 22.77 & 9.39 & 32.20 & 9.41 & 23.00 & 9.76 & 31.45 & 9.63 \\
\hline $\mathrm{LSD}_{0.05}$ & 0.151 & 0.048 & 0.062 & 0.035 & 0.109 & 0.054 & 0.056 & 0.043 \\
\hline \multicolumn{9}{|c|}{ Nitrogen rates $(\mathrm{N})$} \\
\hline $\mathrm{N}_{1}$ & 26.22 & 10.19 & 28.93 & 8.97 & 26.51 & 10.70 & 28.57 & 9.21 \\
\hline $\mathrm{N}_{2}$ & 27.36 & 11.70 & 30.30 & 10.16 & 27.71 & 12.24 & 29.96 & 10.36 \\
\hline $\mathrm{N}_{3}$ & 28.77 & 12.71 & 31.50 & 11.19 & 29.12 & 13.27 & 30.88 & 11.53 \\
\hline LSD $_{0.05}$ & 0.170 & 0.035 & 0.077 & 0.060 & 0.079 & 0.069 & 0.043 & 0.035 \\
\hline \multicolumn{9}{|c|}{ Nitrogen doses(D) } \\
\hline D1 & 26.96 & 11.17 & 29.80 & 9.77 & 27.30 & 11.64 & 29.37 & 10.00 \\
\hline D2 & 27.38 & 11.54 & 30.30 & 10.09 & 27.72 & 12.09 & 29.81 & 10.39 \\
\hline D3 & 28.02 & 11.89 & 30.63 & 10.46 & 28.32 & 12.48 & 30.23 & 10.71 \\
\hline $\operatorname{LSD}_{0.05}$ & 0.054 & 0.058 & 0.043 & 0.051 & 0.249 & 0.119 & 0.106 & 0.075 \\
\hline \multicolumn{9}{|c|}{ The interaction } \\
\hline $\mathrm{I} * \mathrm{~N}$ & $* *$ & $* *$ & $* *$ & $* *$ & $* *$ & $* *$ & $* *$ & $* *$ \\
\hline $\mathrm{I} * \mathrm{D}$ & $*$ & $*$ & $* *$ & $*$ & $*$ & $*$ & $* *$ & $* *$ \\
\hline $\mathrm{N}^{*} \mathrm{D}$ & Ns & $* *$ & $* *$ & Ns & $* *$ & Ns & $* *$ & $* *$ \\
\hline$I^{*} N^{*} \mathrm{D}$ & Ns & $* *$ & $* *$ & $\mathrm{Ns}$ & $* *$ & Ns & $*$ & $*$ \\
\hline
\end{tabular}

*,** are significant at 0.05 and 0.01 probability levels, respectively. interactions showed significant and highly significant effect on the abovementioned studied parameters except $\left(I^{*} \mathrm{D}\right)$ and $\left(I^{*} \mathrm{~N}^{*} \mathrm{D}\right)$ showed no significant effect for root diameter in the first season and top yield in the second growing one. These results are in a great agreement with those reported by Marinkovic et al (2010), Selim et al. (2010),EL-Agrodi et al.(2011) and Aiad et al.(2014).

As illustrated in Fig 4 mean root and top yield ton / fed., are positively correlated with irrigation water applied, cm within the studied range, $\mathrm{R}^{2}=0.973$ and 0.9952 respectively. Correlation equations between irrigation water supply and the studied parameters, root and top yield were as follow:

$\mathrm{Y}=0.7476 \mathrm{x}-17.489\left(\mathrm{R}^{2}=0.97\right)$

$\mathrm{Y}=0.3561 \mathrm{x}-9.6451\left(\mathrm{R}^{2}=0.99\right)$

Where: $\mathrm{Y}$ refer to the studied parameter and

$\mathrm{X}$ refer to irrigation water applied.

Sugar yield, quality and nitrogen content in both tops and roots. values of sugar yield, purity and nitrogen content in both tops and roots were increased under irrigation treatment $\mathrm{I} 1$ in comparison with $\mathrm{I}_{2}$ and $\mathrm{I}_{3}$.
Presented data in Table (8) showed that the mean 

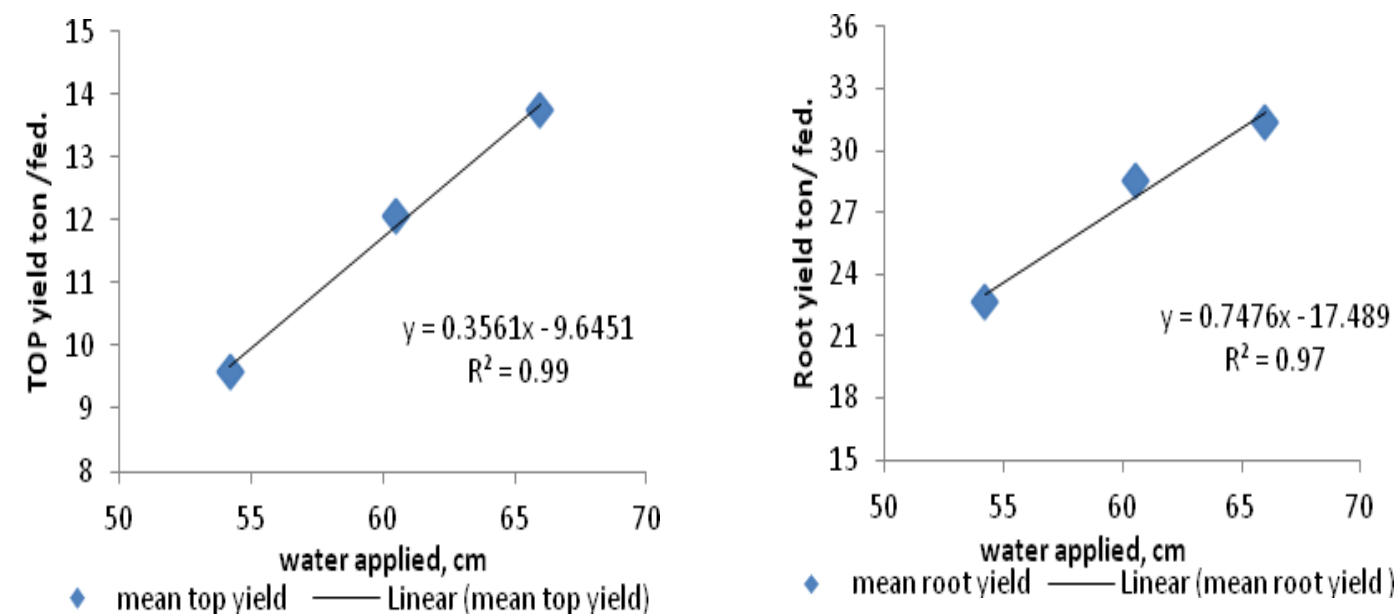

Fig: 4. Correlation between irrigation water applied, $\mathrm{cm}$ and root and top yield ton /fed.

Table 8. Effect of irrigation treatments, nitrogen rates and doses on sugar yield, sucrose, juice purity, nitrogen content in top and roots in the two growing season

\begin{tabular}{|c|c|c|c|c|c|c|c|c|c|c|}
\hline \multirow[b]{2}{*}{ treatments } & \multicolumn{5}{|c|}{$1^{\text {st }}$ growing seasons } & \multicolumn{5}{|c|}{$2^{\text {nd }}$ growing seasons } \\
\hline & $\begin{array}{c}\text { Sugar } \\
\text { yield } \\
\text { Ton/fed } \\
\end{array}$ & $\begin{array}{c}\text { Sucrose } \\
\%\end{array}$ & $\begin{array}{c}\text { Purity } \\
\%\end{array}$ & $\begin{array}{c}\mathrm{N} \\
\text { tops } \\
\% \\
\end{array}$ & $\begin{array}{l}\text { Content } \\
\text { roots } \%\end{array}$ & $\begin{array}{c}\text { Sugar } \\
\text { yield } \\
\text { Ton/fed } \\
\end{array}$ & $\begin{array}{c}\text { Sucrose } \\
\%\end{array}$ & $\begin{array}{c}\text { Purity } \\
\%\end{array}$ & $\begin{array}{c}\mathrm{N} \\
\text { tops } \\
\% \\
\end{array}$ & $\begin{array}{l}\text { Content } \\
\text { roots } \%\end{array}$ \\
\hline \multicolumn{11}{|c|}{ Irrigation treatments (I) } \\
\hline $\mathrm{I}_{1}$ & 5.17 & 16.58 & 84.13 & 2.42 & 1.61 & 5.19 & 16.47 & 84.52 & 2.44 & 1.62 \\
\hline $\mathrm{I}_{2}$ & 5.00 & 17.63 & 82.07 & 2.18 & 1.49 & 4.99 & 17.36 & 82.84 & 2.21 & 1.51 \\
\hline $\mathrm{I}_{3}$ & 4.23 & 18.59 & 79.74 & 1.88 & 1.15 & 4.18 & 18.19 & 80.33 & 1.90 & 1.17 \\
\hline $\mathrm{LSD}_{0.05}$ & 0.033 & 0.047 & 0.092 & 0.033 & 0.030 & 0.023 & 0.048 & 0.097 & 0.045 & 0.055 \\
\hline \multicolumn{11}{|c|}{ Nitrogen rates $(\mathbf{N})$} \\
\hline $\mathrm{N}_{1}$ & 4.73 & 18.14 & 84.55 & 1.96 & 1.28 & 4.71 & 17.85 & 85.07 & 1.99 & 1.30 \\
\hline $\mathrm{N}_{2}$ & 4.78 & 17.59 & 81.41 & 2.14 & 1.43 & 4.77 & 17.30 & 81.74 & 2.16 & 1.45 \\
\hline $\mathrm{N}_{3}$ & 4.88 & 17.07 & 79.99 & 2.37 & 1.53 & 4.89 & 16.87 & 80.88 & 2.39 & 1.54 \\
\hline $\operatorname{LSD}_{0.05}$ & 0.031 & 0.056 & 0.083 & 0.052 & 0.038 & 0.022 & 0.045 & 0.082 & 0.060 & 0.060 \\
\hline \multicolumn{11}{|c|}{ Nitrogen doses(D) } \\
\hline D1 & 4.63 & 17.30 & 81.31 & 1.82 & 1.24 & 4.62 & 17.03 & 81.91 & 1.85 & 1.26 \\
\hline $\mathrm{D} 2$ & 4.79 & 17.59 & 81.97 & 2.16 & 1.43 & 4.78 & 17.35 & 82.53 & 2.19 & 1.45 \\
\hline D3 & 4.99 & 17.91 & 82.66 & 2.49 & 1.57 & 4.97 & 17.64 & 83.25 & 2.50 & 1.58 \\
\hline $\operatorname{LSD}_{0.05}$ & 0.011 & 0.052 & 0.098 & 0.045 & 0.115 & 0.051 & 0.052 & 0.126 & 0.064 & 0.142 \\
\hline \multicolumn{11}{|c|}{ The interaction } \\
\hline $\mathrm{I} * \mathrm{~N}$ & $* *$ & $* *$ & $* *$ & $* *$ & Ns & $* *$ & $* *$ & $* *$ & $* *$ & Ns \\
\hline $\mathrm{I} * \mathrm{D}$ & $*$ & $* *$ & $* *$ & $* *$ & Ns & $* *$ & $* *$ & $* *$ & $* *$ & Ns \\
\hline $\mathrm{N} * \mathrm{D}$ & $* *$ & Ns & Ns & $*$ & $\mathrm{Ns}$ & $*$ & Ns & $* *$ & Ns & Ns \\
\hline $\mathrm{I} * \mathrm{~N} * \mathrm{D}$ & Ns & $* *$ & $* *$ & $*$ & Ns & $* *$ & $* *$ & $* *$ & Ns & Ns \\
\hline
\end{tabular}



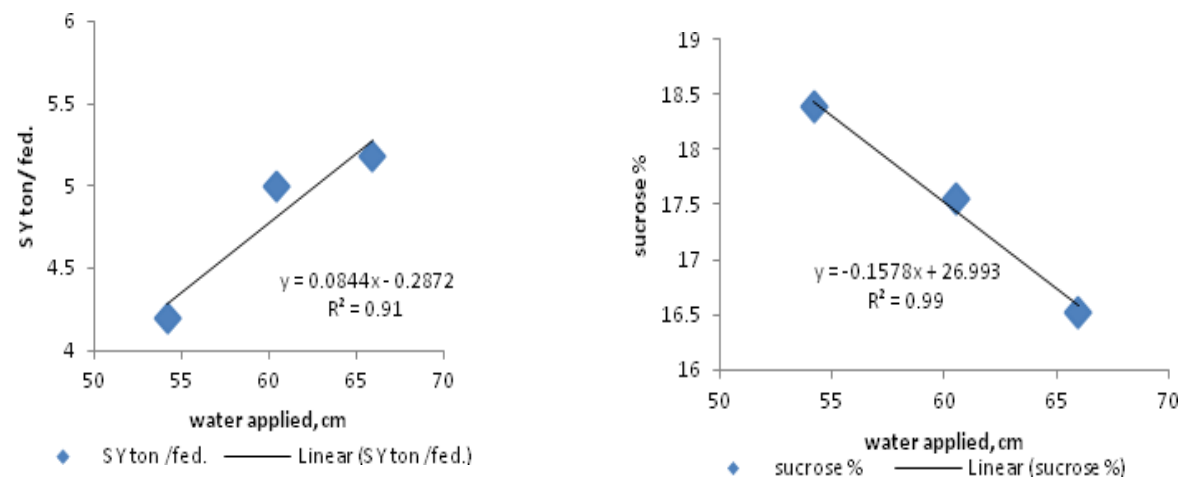

Fig 5. Correlation between irrigation water applied, $\mathrm{cm}$ and sugar yield, sucrose \%

On the contrary, the highest mean values for sucrose $(\%)$ were recorded under irrigation treatment $\mathrm{I} 3$ in the two growing seasons. The highest mean values are 5.17 and 5.19 ton fed. for sugar yield, 84.13 and $84.52 \%$ for purity, 2.42 and $2.44 \%$ for nitrogen content in tops and 1.61 and $1.62 \%$ for roots in first and second seasons respectively. Although, the highest mean values for sucrose $\%$ are 18.59 and $18.19 \%$ under $\mathrm{I}_{3}$ in the first and second growing seasons respectively. These are in a great harmony with those obtained by Shabana (2010) and Gharib and El-henawy (2011). Regarding the effect of nitrogen rates on the abovementioned studied parameters. The highest mean values of sugar yield, and nitrogen content in both tops and roots were recorded under $\mathrm{N}_{3}$. On the contrary, the highest mean values for sucrose (\%), and purity (\%) were recorded under $\mathrm{N}_{1}$ in the two growing seasons. Concerning with the effect of nitrogen splitting, the highest for all the abovementioned studied were recorded under splitting nitrogen into three equal doses $\left(\mathrm{D}_{3}\right)$ in the two growing seasons.

The interactions between all studied parameters $\left(I^{*} \mathrm{~N}\right),\left(I^{*} \mathrm{D}\right),\left(\mathrm{N}^{*} \mathrm{D}\right)$ and $\left(\mathrm{I}^{*} \mathrm{~N} * \mathrm{D}\right)$ showed significant and highly significant effect on the studied parameters except nitrogen content in roots showed no significant effect.

Figure (5) showed the correlation between irrigation water applied and sugar yield there was appositive but, water applied negative relationships with sucrose $\%$.

\section{CONCLUSION}

Overall, our investigations with sugar beet showed that irrigation with treatment $\mathrm{I}_{1}$ (irrigation at $55 \%$ depletion of available soil moisture) was successful and acceptably precise for research objectives; highest yield, quality, nitrogen content in both roots and tops and also the highest values of water productivity and productivity of irrigation water. So, this study recommended that sugar beet under the studied area should be irrigated at $55 \%$ depletion of available soil moisture and spitting nitrogen in three equal doses.

\section{REFERENCES}

Abo Soliman,M.S.; H.E.Osman; M.M.Saied and E.H.Omar. 2005. Maize, barley production and water use efficiency as influenced by different irrigation methods in Egyption old land. Role and horizons of agricultural Engineering in the contemporary world. The $13^{\text {th }}$ Conference of the Misr.Society of Agr.Eng., 14-15December (2005).

Adekalu,K.O. and Okunade D.A. 2006. Effect of irrigation amount and tillage system on yield and water use efficiency of Cowpea. Communication in soil sci. and plant analysis, 37.225-228.

Aiad,M.A.;E.A.Moursi;R.A， EL-Dissoky AndM.M.Amer. 2014. Response of maize crop to irrigation under different rates and doses of nitrogen fertilization in the North Nile Delta region.J.soil sci and Agric .Eng. Mansoura Univ.Vol. 5(1):97-113, 2014.

Ali,M.H.;M， R.Hoque,A.A.Hassan And A.Khair. 2007. Effects of deficit irrigation on yield water productivity and economic returns of wheat. Agricultural water management,92(3):151-161.

Ancuta puscas,E.luca and A. ceclan. 2007. The effect of the climate and soil conditions sugar beet yield increase and stabilization in Transylvania's filed conditions. Bulletin of university of Agriculture sciences and veterinary medicine cluj-Napoca-Hcrticulture, vol 64,No1-2.

Beshara,A.T. 2012.Effect of soil moisture depletion and nitrogen fertilizer application date on wheat yield, water and fertilizer use efficiencies in north Africa.Ph.D.thesis: Fac.of.Agric.Cairo univ.;Egypt.

Byan,UsryaA, M.Z.El-shinawy; Hosnia, M.Gomaa and M.H.Mahmoud. 2002 Yield and water relations of Cowpea and Pea plants as affected by water regime.Arab.Univ.J.of Agri.Sci,10(3),Issn1110-2675.

Chapman,H.D.and P.F.pratt. 1961.Methods of analysis for soil plants and waters. Univ.of Calif.Division of Agric.Sci,6069. 
Early,A.C.(1975). Irrigation scheduling for wheat in the Punjab CENTO scientific program on the optimum use of water in Agriculture .Report No.17,Lyallpur,Pakistan, March,3-5,pp.115-127.

El-Agrodi,M.W.;A.M.EL-Ghamry and W>M.Lashin. 2011. Maize Response to nitrogen Rate and splitting in sandy clay loam soil. J.soil Sci.and Agric.Eng.,Mansoura Univ,.2(8)775-788

EL-Attar,H.A; Y.A.Darweesh; M.K.EL-Haris, and F.A.Askar. 1995. The effect of NPK fertilization on the yield components of sugar beet at northern Nile Delta J.Agric.sci.MansouraUniv.20(7);3635-3643.

EL-Mowlhi,N.M,; AbdEL-Hafez,S.A.; EL.Sabagh,AA.and Abo-Ahmed,A.L. 1999. Evaluation of drip irrigated maize in north Delta Egypt Third Conference of on .Farm irrigation and agroclimatology. January25-27,1999, Vol.1.

Gharib S. H. and A.S. El.Henawy. 2011. Response of sugar beet to irrigation Regime,Nitrogen rate and mocronutrients application.Alex.science exchange Journal,Vol.32 No.2 April-June.2011.

Gomez,K.A.and A.A.Gomez. 1984. Statistical procedures for Agricultural Research,Second Ed.Willy and Somne Inc.New York.

Hansen,V,w.; Israelsen and Q.E-Straingharm. 1979. Irrigation Principles and Practices, $4^{\text {th }}$ ed, Jhon Willey and sons, New York.

Israelsen,O.W and V.E,Hansen. 1962. Irrigation Principles and Practices $/ 3^{\text {rd }}$ edit.John Jhon Willey and sons Inc, New York.

Jackson,M.L. 1973.soil chemical analysis advancedcourse.Ed.2.A manual of methods useful for instruction and research in soil chemistry,Physical chemistry of soils, soil fertility and soil genesis. Revised from original edition 1956.

Kayombo,B,SimalengaT.E, and Hatibu N. 2002. Effect of tillage methods on soil physical condition and yield of beens in sandy loam soil. Agricultural Mechanization in Africa, Asia and latin America, 33(4):15-18.

Khalifa,M.R; F.I.Header. 1995. Responseof sugar beet to $\mathrm{N}, \mathrm{Zn}$ and Mn fertilization under different level of soil salinity. J.Agric.Res. Tanta univ., 21(4):770-778.

Klute,A.(1986).Methods of soil analysis (part 1).Amer.Soc.of Agron; Inc.Madison,Wisconsin,USA. $3^{\text {rd }}$ edition.

Marinkovic,b.,J.crnobarac;G. Jacimovic; M.Rajic;D. latkovic;V.Acin. 2010. Sugar yield and technological quality of sugar beet at different levels of nitrogen fertilization. Res,J,Agric.Sci.;42(1):162-167.
Mona.S.M.Eid. 2012. IrrigationScheduling for sugar beet crop by using pan evaporation method in Nile Delta .MSC Thesis ,soil Dept $>$ Fac.of Agric.Mansoura Univ;Egypt.

Morillo-Velarde,-R. 2000. Irrigation history and prospects . 63e-Congres-Institut-International-de-Recherches-

Betteravieres,-Interlaken,-Switzerland,-9-10-fevrier; 135145

Moursi,E.A. 1997. Some soil properties and sugar beet yield as affected by ploughing depth and fertilization in salt affected soil MSC.Fac.of Agric.KaferEL.sheikh.tanta.univ.

Panda,R.K.;S.K.Behera, and P.S.Kashyap. 2004. Effective management of irrigation water for maize under stressed condition. Agricultural water management .66(3):181-203.

Rezk,S.A.M.;M.A.M.Sherif and A.A Sakr. 1995. Effect of nitrogen and boron supply in highly Calcareous soil in the growth and yield of sugar beet . Zagazig.J.Agric. Res 22(4):1157-1166.

Richer, G. M, Jaggerd, K.W, Mitchell, R.A.C. 2001. Modelling radiation interception and radiation use efficiency for sugar beet under variable climatic stress. Agric. For. Meteorol. 109,13-25

Rytter,R.M. 2005. Water use efficiency, carbon isotope discrimination and biomass production of two sugar beet verities under well watered and dry condition. Journal of agronomy and crop science. 191(13)426-438.

Selim,E-M.; Z.M.El-Sirafy and A.A.Taha. 2010. Effect of irrigation methods and n-applications on the utilization of nitrogen by sugar beet Grown under Arid condition. Australian J.Basic nand applied Sci.,4(7);2114-2124.

Sepaskhah,A.R.Kamgar.Haghighi,A.A. 1997. Water use and yields of sugar beer grown under every other furrow irrigation with different irrigation intervals agric. Water mange .34,71-79.

Shabana.M.M. Abd EL-Hay. 2010. Evaluation of using some modern irrigation technigues to improve surface irrigation system and its effect on nitrogen use efficiency MSC. Thesis,soil Dept.Fac.of Agric.Mansoura,Univ,Egypt.

Singh, R.V., and H.S. Chauman. 1996. Irrigation scheduling in wheat under shallow water table conditions. p 103-108. In: C. Camp, E. Sadler, and R. Yoder (eds.). Evapotranspiration and Irrigation Scheduling. A.S.A.E. San Antonio, Texas, USA.

Singhania,R.A. and R.k.Shaima. 1990. Effect of nitrogen requirement of sugar beet in saline-sodic soils. J. Indian Soc.Soil .Sci.,38(2)-330-332.

Waller, R.A.and D.B.Duncan. 1969. Symmetric multiple Comparison problem.Amer.Stat.Assoc.Jour.December,1485-1503. 


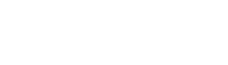

تالثير الري والتسميد النيتروجيف علي محصرل بنجر اللسكر وجونة وكذك بهض الملفلت المائيةفي

\section{الاراضي اللينية القيلة}

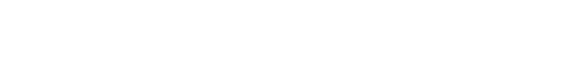

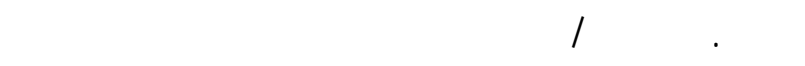

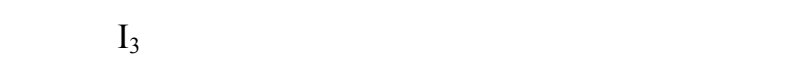

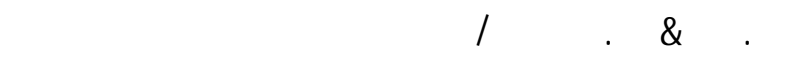

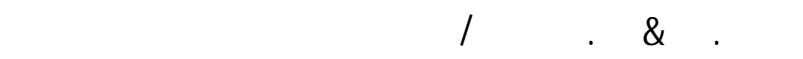

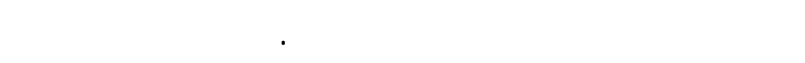

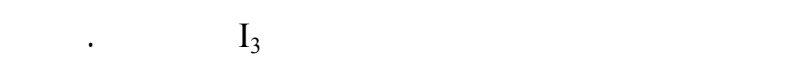

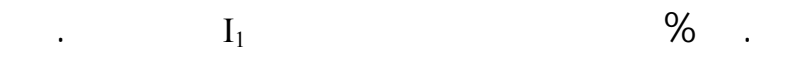

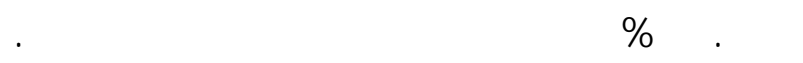

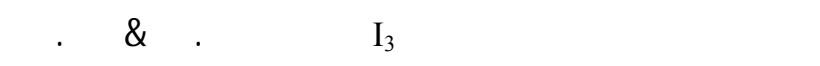

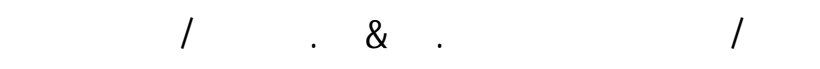

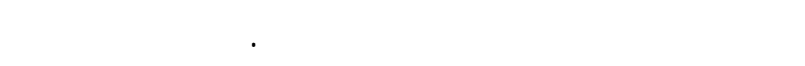

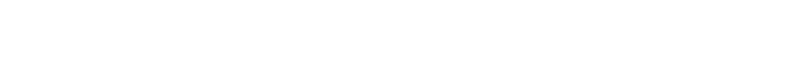

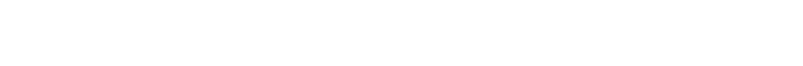

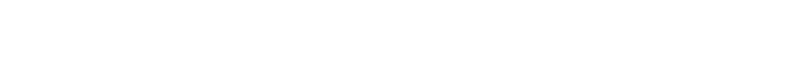

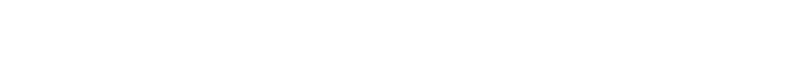

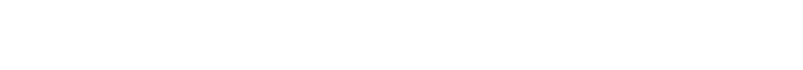

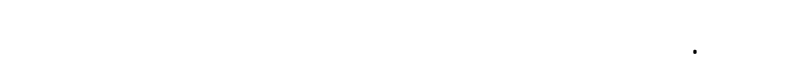

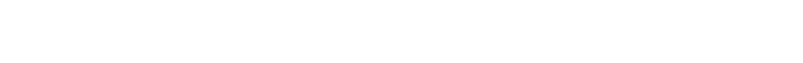

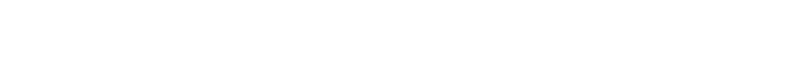
وطل الجذور.محصول للسكر والنتروجين في المجم -وع

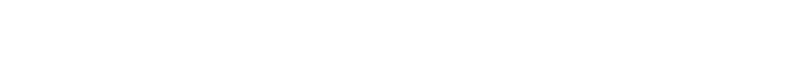
النتيتروجيني مع جرعلت الاضفة الاعلي وتجزئة اللد ماد

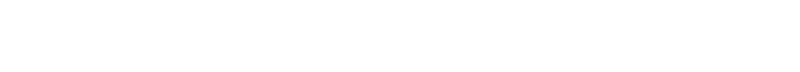

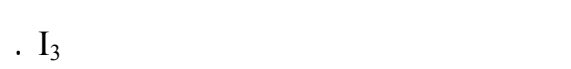

لجريت تجربتان حقليتان فى مزرعة مطط ـة البح ـوث

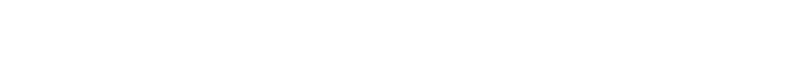

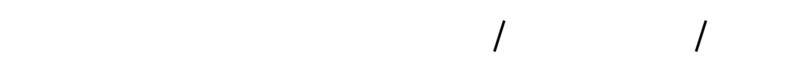

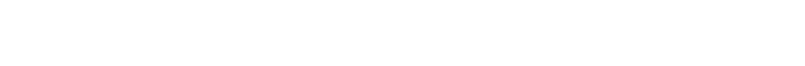

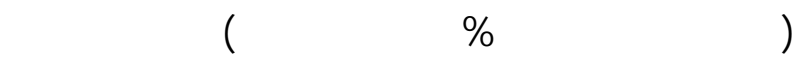

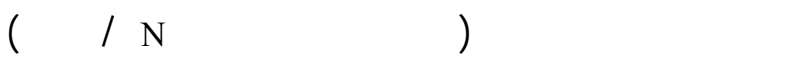

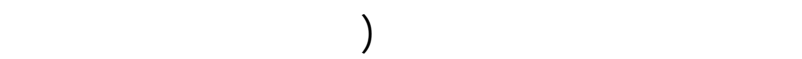

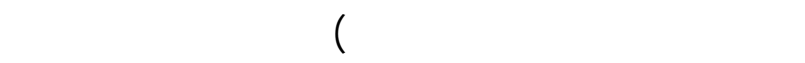
اللسكر وجونتة وبعض العلاقلت المائية، تركيز النيتروجين فينان في النبات فى مطقة شمل وبط الدلتا - التحليل الإحصائى

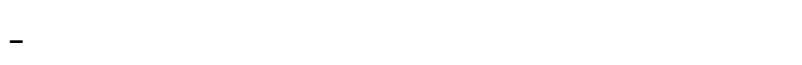
المعلملات الرئيسية هـ معلملات الرى - بينما المع ـالملات تهت الرئيسية هي جرعات الإضافة، والمع مالملات تح ـات

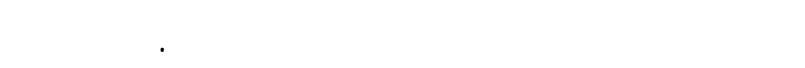
النتائج الي المئية بالنسة لاعلي قيم الماء المضف والماءد نتهلاك الم ائي

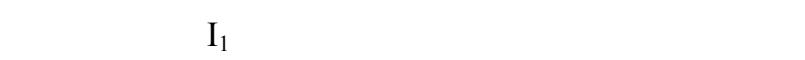

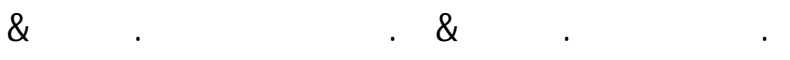

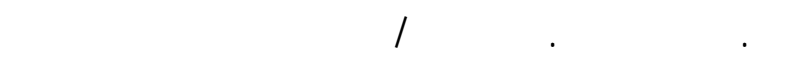

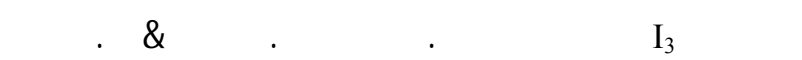

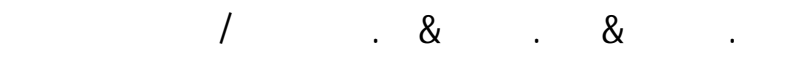

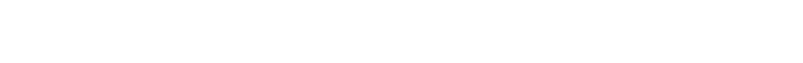

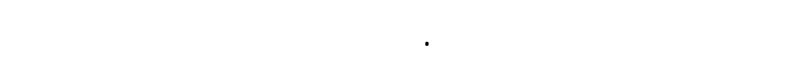
الميل المستهلكة والمضافةسجلت تهت العالملة Iالمان والفيم هي

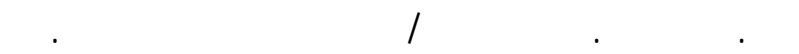

